\title{
Activities and Events
}

\section{November, 2017 \\ Opening of the $3^{\text {rd }}$ Academic Year}

\author{
Katja Maria Vogt, Columbia University, New York/USA \\ The Nature of Disagreement: Ancient Relativism and Scepticism
}

Pyrrhonian scepticism has roots in metaphysical discussions relevant to relativism. The lecture reconstructed these discussions in Plato's Theaetetus and explored how different versions of Pyrrhonian scepticism-the scepticism of Pyrrho, Aenesidemus, and Sextus Empiricus-compare to Protagorean relativism. It began with a sketch of why Plato interprets Protagoras' 'Measure Doctrine' as global relativism rather than relativism about a particular domain. Pyrrhonian scepticism, it was argued, inherits this global scope. But Pyrrhonian responses to disagreement have important differences from the responses envisaged by Protagorean relativism. Scepticism suggests that, when encountering disagreement, it is rational to step back from one's view and investigate, rather than simply to hold on to one's view, as the relativist presumably does. The lecture defended scepticism's response to disagreement as construed by Sextus Empiricus as being superior to earlier proposals.

\section{Regular Events}

\section{Dialectical Evenings}

The Dialectical Evening is an informal meeting every four weeks (in fortnightly rotation with the Reading Evening) for discussions and readings, which is designed to promote dialectical culture and sceptical thought within the research unit. Members of the Maimonides Centre and occasional guests convene to challenge, doubt, and explore theses in various subject areas.

[DE 17] 21 November, 2017

Giada Coppola and Michael Engel: On the Eternity of the Movement of Generation and Destruction

The Jewish thinker Obadiah ben Jacob Sforno (c. 1475-1550) is considered to be the last Jewish scholastic author. He is best known for his biblical commentaries and exegetical activity, although he also wrote a philosophical treatise entitled The Light of 
the Nations. The work was published in Hebrew in 1537 with the title Or 'Ammim. The author himself then translated it into Latin, revising it significantly in order to address its content to the Christian humanist audience (Lumen Gentium, 1548). The text strives to reproduce the classical scholastic form of argument (summa) and attempts to refute Averroes' Aristotelianism by using the Aristotelian method to subvert and undermine its own doctrines in order to elevate the Jewish religious dogmatic concepts.

The opening quaestio of The Light of the Nations aimed to confute the eternity of the movement of generation and destruction (also known as the coming-to-be and ceasing-to-be). Sforno presents three arguments in favour of the eternity of generation and destruction (pro) and five (four in the Latin version) counterarguments (contra). As expected, the quaestio is solved with a negative answer: the movement of generation and destruction is not eternal, but Sforno's conclusion gives rise to a new difficulty.

[DE18] 23 January, 2018

Friedhelm Hartenstein and Hanna Liss: The Torah as a Material and Verbal Medium of the Divine Presence

This Dialectical Evening asked how the ritual practices of ancient and modern Judaism reflect on the fundamental human need for images from two different points of view (Protestant biblical exegesis and Jewish studies). In the light of the explicit biblical prohibition of cultic images, it is interesting that the Torah scroll and its ritual reading in the synagogue share some characteristics with the veneration of divine images or other symbols of the presence of God. The thesis Friedhelm Hartenstein and Hanna Liss discussed was that the interplay between visible objects and mental images of the divine is a common element of religious practice in general: without 'material anchors' there are no religious symbols at all. If this is true, the explicit formulation of the biblical image ban by the exilic authors seems to presuppose a growing insight into a basic condition of humanity: the need and desire for images. The authors of the biblical texts were well aware of this need and of the dangers of human attention often being fixated only on the object itself and thereby possibly getting lost in immanence (cf. Exodus 32). How did the Bible and later Jewish traditions solve the unavoidable tension between the necessity of images and the confusion caused by treating them as idols? And how can exegetical insights contribute to Jewish studies in this respect? Do the categories of visual science (Bildwissenschaft) help to clarify the specific status of the Torah scroll in Jewish worship as a 'non-idolatric' cultic artefact? And finally: what are the possible implications for the question of Jewish scepticism? 
[DE19] 10 April, 2018

José María Sánchez de León Serrano and Ze'ev Strauss: Jewish Appropriations of Hegel's Philosophy of Religion

Hegel's philosophy, in particular his philosophy of religion, played a crucial role in the way nineteenth century Jewish philosophers conceived their own religion. Thinkers like Nachman Krochmal (1785-1840), Salomon Formstecher (1808-89), and Samuel Hirsch (1815-89) developed a philosophy of Jewish religion based on Hegelian premises and articulated through Hegelian concepts. At the same time, they opposed Hegel's dismissive view of Judaism as a stage of religious consciousness that would be-along with Greek and Roman paganism-surpassed by Christianity. Thus, by presenting Judaism as the true religion of the Absolute (instead of Christianity), they attempted to refute Hegel's view of Judaism with Hegel's own logic. In this Dialectical Evening, the convenors discussed the assumptions, limits and strengths of Jewish appropriations of Hegel.

[DE20] 8 May, 2018

Michael Engel and Yoav Meyrav: Elijah Del Medigo between Philosophy and Religion

Elijah Del Medigo (c. 1460 -93), a Cretan Jewish author living and working in Northern Italy, wrote about Aristotelian themes in Hebrew and Latin and is considered a 'Jewish Averroist.' Drawing on his different works, contemporary scholars have attempted to discern Del Medigo's general attitude toward the relation between philosophy and religion. In this evening, we asked whether a coherent approach to this relationship can indeed be extracted from Del Medigo's corpus, or whether he adopted a more ad hoc approach, adapting his view in a given context to his audience. The specific case of Del Medigo was then expanded to a general methodological discussion about scholars' tendency to search for a cohesive meta-philosophical approach within other medieval Jewish authors.

[DE21] 5 June, 2018

Timothy Franz and José María Sánchez de León Serrano: The General Pattern of

\section{Solomon Maimon's Philosophy}

The works of Solomon Maimon (c. 1753-1800) published in his lifetime extend from 1789 to his death in 1800. Drawing largely on the perspective of his Autobiography (1792-93) and arguments from the Essay on Transcendental Philosophy (1790), scholars have written commentaries on Maimon which interpret him as an aporetic thinker, a sceptic, or a severe combination of rationalist dogmatist and empirical sceptic. Since Maimon combined his acute scepticism with ambitious and evolving theolog- 
ical speculations, we asked whether a broader view of his thought can be taken, also involving later works which have escaped the notice of tradition. And if this general pattern is found, what does this mean for Maimon as a Selbstdenker and for our philosophical and cultural traditions?

[DE22] 24 July, 2018

Stephan Schmid and Oded Schechter: Spinoza's Scepticism about Religion? The Question of Secularism in the TTP

Spinoza's Theological Political Treatise (anonymously published in 1670 as Tractatus Theologico-Politicus or TTP for short) is, next to Hobbes' Leviathan, often described as the founding text of modern and secular political philosophy. But in what does the secular moment of Spinoza's TTP consist? According to an influential line of commentators-comprising such famous scholars as Strauss and Nadler-Spinoza's secularism is identified in his questioning of the authority and truth of the Bible. For among the main claims defended in Spinoza's TTP are those that the Bible is but a historical document and no 'Letter God has sent men from heaven' (12.1), that prophecy is but a form of imagination, that miracles are just unusual as opposed to super-natural events, and that the goal of Scripture consists in instilling obedience, and not in conveying some super-natural truth. In this Dialectical Evening, Stephan Schmid and Oded Schechter wanted to present this secularist or sceptical reading of Spinoza's TTP and explore the tenability of the opposing view. According to this opposing view, far from discarding religion and considering it a useful means to control the superstitious masses, Spinoza takes revelation to be an integral element of the modern state, which leaves room for free political agency.

[DE23] 7 August, 2018

Bernard Cooperman: Cultural Pluralism Seen from the Ghetto or: Is Tolerance Possible in a Religious Society?

Bernard Cooperman presented a series of texts by a range of Jewish writers dating from the second half of the sixteenth and first half of the seventeenth centuries. These texts, written originally in Hebrew, Italian, and Latin, seem to express quite radical positions about the relation between Christianity and Judaism and the possibilities of Jews living within Christian society. The first three authors, all of whom lived in Venice at least for a while, include a Portuguese-trained New Christian physician (Elijah Montalto) who became famous as a Jewish polemicist, a Jewish physician (David de' Pomis) trained at the University of Perugia who lost his right to practice medicine on Christians, and a rabbi (Simone Luzzatto) who is well known as a defender of the Jewish presence in his city. All three men, not irrelevantly, authored significant works aimed at a non-Jewish audience, works devoted to medical science, 
lexicography, and philosophical scepticism respectively. All three represent the type of (Jewish) intellectual whose career and writings elucidate the transitional position of those who enter into another world of discourse and claim status within it without abandoning their claims to independent status. Finally, Cooperman used their arguments to offer a contextualisation of Spinoza's Theological-Political Tractate that may help to understand why the Dutch author presented the relation between religion and the state as he did.

\section{Reading Evenings}

The Reading Evening is an informal meeting every four weeks (in fortnightly rotation with the Dialectical Evening). Fellows and researchers read and discuss primary texts that are specifically relevant to their respective projects. Each meeting, one fellow or research team member selects and presents a text of particular importance for her research. In reading together, the group benefits from the expertise of the individual researcher.

[RE16] 8 August, 2016

Máté Veres: Scepticism about Theology in Sextus Empiricus

Given the prevalence of religious diversity in the Graeco-Roman world and the dominance of theological tenets in the philosophy of the time, it is hardly surprising that reflections concerning the rationality of religious belief came to the fore in the Hellenistic age. Importantly, both religious and anti-religious dogmatism proved to be a prime target for sceptical examination, as evidenced by Sextus Empiricus, a Pyrrhonian sceptic and our primary source for the early encounter between scepticism and dogmatic theology. The Reading Evening was focussed on some arguments concerning theology as they are presented by Sextus in his Outlines of Pyrrhonism, Book III, and parts of his Against the Physicists, Book I.

[RE17] 5 September, 2017

Ehud Krinis: Judah Halevi's Use of Sceptical Arguments

Articles 11-25 in Book I of Judah Halevi's Kuzari form the opening section of the dialogue between the Khazar king and the Jewish sage (the haver). It is in this section that Halevi presents his definition of Judaism vis-à-vis the dogmatic-rationalistic definition of religion. In this section, we can detect Halevi's most elaborated use of some sceptical arguments. The Reading Evening was devoted to the examination of Halevi's use of sceptical arguments in I, 11-25 as part of his elucidation of the uniqueness of the Jewish religion. 
[RE18] 24 October, 2017

Thomas Meyer: The Quest for Certainty in Saadiah's Philosophy

Abraham Joshua Heschel's article “The Quest for Certainty in Saadiah's Philosophy” is an important contribution to Jewish scepticism on at least three levels: as a close reading of Saadiah's concept of 'certainty', as part of Heschel's own theology (for example 'God in Search of Man'), and as an example of the use of medieval thinkers and their concepts during the Second World War. The aim of the Reading Evening was to understand how one and three are mixed and what that means for our interpretation of Jewish scepticism (keywords: historicism, systematical vs. historical reading, persecution and the art of writing, etc.).

[RE19] 19 December, 2017

Friedhelm Hartenstein: Is the Book of Job a Work of Sceptical Literature?

This Reading Evening raised the question whether the biblical book of Job could be characterised as a work of sceptical literature. Hartenstein considers the dissertation of Katherine J. Dell (supervised by John Barton, University of Oxford, 1988) as the only monograph which is explicitly dealing with the question in considerable length-taking into account aspects of content as well as of form. Dell follows a more open definition of scepticism with regard to Greek sceptics (cf. pp. 168-171). The discussion was based on chapter 4 of this thesis as well as on various chapters of the book of Job (ch. 1-7; 19; 38 and 42).

[RE20] 16 January, 2018

Andreas Brämer: Abraham Geiger-A Reluctant Pioneer of Systematic Theology?

Andreas Brämer's research at the Maimonides Centre was dedicated to Rabbi Abraham Geiger (1810-74), both an intellectual spearhead of liberal Judaism and an iconic figure of critical Jewish scholarship in Germany during the era of Verbürgerlichung. Considering the fact that Geiger, rabbi first in Wiesbaden, then in Breslau, Frankfurt and Berlin, was so eager to define 'jüdische Wissenschaft' as a Jewish theology, it may seem appropriate to enquire after Geiger's contributions to a systematic description of the Jewish belief system. The Reading Evening was based on a number of passages from Geiger's private correspondence that have been published in German as well as in English translation in order to comprehend his rather reluctant stance when it comes to the presentation of doctrines of faith. 
[RE21] 20 February, 2018

Zev Harvey: Ḥasdai Crescas' Scepticism about Proofs of God

Medieval philosophers, like Avicenna, Maimonides, or Thomas Aquinas, composed famous 'proofs of God.' God, they held, is found not only in Holy Scripture, but also in the physical or metaphysical demonstrations of philosophers. The Catalan Rabbi Hasdai Crescas (c. 1340-1410 or 1411), in his Hebrew philosophical book The Light of the Lord (Or Adonai), was profoundly sceptical about such proofs. One may prove a first cause of our world, he allowed, but there may be many worlds, perhaps an infinite number of them, and each world could have its own first cause, that is, each could have its own God. Reason, he concluded, has no way of freeing itself from doubt. Only prophecy, he argued, truly proves the existence of One God. The aim of this Reading Evening was to understand the motives, spirit, and scope of Crescas' scepticism.

[RE22] 6 March, 2018

David Ruderman: Defending the Integrity of Rabbinic Judaism in Nineteenth-Century Europe: The Creative Response of Isaac Baer Levinsohn to the Missionary Assaults of his Day

Alexander McCaul (1799-1863) was one of the most prominent figures in The London Society for promoting Christianity amongst Jews during the first half of the nineteenth century. In 1837, he published a formidable attack against the Talmud entitled The Old Paths, engendering considerable consternation and alarm among Jews when the work appeared in Hebrew translation two years later. His work evoked a series of long responses from Jewish intellectuals attempting to defend traditional Judaism from his stinging criticisms, especially several written by Eastern-European maśkilim (proponents of the Jewish enlightenment) who had previously condemned the rabbis and their restrictive Talmudic laws in calling for radical religious and educational reform. The irony of these same critics of Rabbinic Judaism feeling obliged to defend their hallowed traditions is at the heart of Ruderman's study of McCaul's critique and the Jewish response.

David Ruderman examined in the Reading Evening the response of Isaac Baer Levinsohn (Ribal, 1788-1860), the most important figure in this group, and his bold attempt to articulate the relevance of Jewish civilisation for Christians and Jews alike. Armed with vast erudition in Rabbinic sources, knowledge of ancient and modern history, and broad exposure to contemporary scholarship, Ribal offered not merely a thorough answer to McCaul but a thoughtful and nuanced articulation of how Judaism might retain its authentic character while reforming itself in the light of the new exigencies and challenges of the modern era. 
[RE23] 24 April, 2018

Diego Lucci: The Limits of Human Understanding in John Locke's Philosophy: Political Scepticism, Moral Scepticism, and Ontological Scepticism

John Locke (1632-1704) is widely known as the founder of modern empiricism and the father of liberalism. However, not many people are aware of the sceptical aspects of Locke's philosophical, political, moral, and religious thought. The sceptical dimension of Locke's thought manifests itself in different ways in his reflections on religious toleration, the foundations of morality, and the scope of human knowledge. Locke's rejection of the imposition of 'true religion' in A Letter concerning Toleration (1689) mainly relies on a sceptical argument-the argument from error. Moreover, Locke's moralist soteriology in The Reasonableness of Christianity (1695) largely resulted from his attempt to overcome his own moral scepticism. Furthermore, in An Essay concerning Human Understanding (1690), Locke denied that we could get behind ideas to things themselves, in that he defined substance as an unknown substratum or support of qualities-thus discarding the metaphysical concepts that underlie the trinitarian dogma and other Christian beliefs, as Edward Stillingfleet and other contemporary critics noted. Nevertheless, Locke did not call into question the existence of true religion, the demonstrability of morality, or the actuality of substances. What he doubted was the human capacity to actually comprehend and communicate religious truth, to find solid foundations for morality, and to know any substance. Briefly, Locke's sceptical attitude originated in his recognition of the limits of human understanding.

[RE24] 22 May, 2018

\section{Lukas Lang: Common Sense and Scepticism}

There is a tradition in philosophy, which began with Berkeley and Reid and continues up until today, that opposes scepticism with common sense. A common-sensebased attack is especially threatening because it allegedly rests on no assumptions or because it proceeds from a pretheoretical point. Other attacks on scepticism do rest on assumptions, and this weakens their position in the sense that the sceptic can (try to) resist them. However, Lukas Lang wanted to argue that a commonsense-based attack requires an obvious contradiction between common sense and scepticism. If they are not obviously contradictory, then the contradiction must be shown, presumably by argument, and so a common-sense-based attack would lose its chief advantage of ruling out scepticism prior to philosophical discussion. The problem is most obvious when we turn towards Moore's list of common sense truths ('There exists at present a living human body,' and so on) and Berkeley's assent to them. In Berkeley's theory, all common sense propositions are rendered true. But then there is no contradiction, not even disagreement, for the attacker to use a common sense proposition against Berkeley. With this situation in mind, Lukas Lang 
surveyed both sides of the debate: on the one hand, the common sense conception of Moore and Berkeley; on the other hand, the conception of contemporary Mooreans such as David Lewis and Jonathan Schaffer. Additionally, he took a look at two attempts to reach a contradiction between common sense and scepticism, namely via a theory of meaning or via Reid's theory of perception. Both, he argued, either fail because they are too weak or because they can claim no support from common sense and so gamble away the attack's main advantage.

[RE25] 19 June, 2018

Guido Bartolucci: Jewish Scepticism in Christian Eyes

In 1704, the Lutheran scholar Jakob Friedrich Reimmann (1668-1743) anonymously published a treatise on Solomon as a sceptic philosopher. He maintained that all the Jewish Patriarchs could be interpreted as sceptic philosophers, and in order to demonstrate his statement, he examined the figure of Solomon. The work is divided into two parts: in the first part, Reimmann shows the links between Solomon's philosophy and sceptic philosophy. In the second part, he defends his statements from the accusation of one philosopher and theologian, Joachim Lange, by maintaining that scepticism is the only true philosophy because it is based on the idea that 'man knows nothing.' Reimmann maintains that after Adam's fall the human mind could no longer attain true knowledge of the world: only God could give men vera sapientia, true wisdom. By quoting passages from different books of the Old and the New Testament, Reimmann used the classical fideistic instruments of scepticism in order to demonstrate the weakness of the human mind. He argues that Solomon was the best example of the Jewish philosophical tradition, and he also adds that because the Jewish king lived centuries before Pyrrho, he could therefore be seen as the real founder of scepticism. The relationship between scepticism and the Jewish tradition, according to Reimmann, was to strengthen the main characteristic of that kind of Greek philosophy, that is, its acknowledgement of human ignorance and doubt. Reimmann, however, uses the fideistic garb in order to legitimise the sceptical strategy towards dogmatism and traditional knowledge. During the Reading Evening, the first part of the work (translated into English for the first time) was read and Reimmann's interpretation of scepticism was discussed.

[RE26] 3 July, 2018

Jürgen Sarnowsky: Miracles and Saints in Doubt

During the later Middle Ages, the number of pilgrim places increased, as did the number of saints and relics. People were looking for support in their daily lives or collected indulgences for the salvation of their souls and to further their afterlives. Even if many people believed in what they were told by the clerics in these places 
of veneration, others, inside as well as outside the ecclesiastical sphere, doubted. This collection of sources for the Reading Evening offers examples from three cases: the 'Holy Blood' of Wilsnack, the canonisation process of Dorothea von Montau at Marienwerder in Prussia (1404), and the pilgrim's report of Arnold von Harff (1496-98). While the events in Wilsnack were doubted from the beginning and became the subject of a theological debate, the hearing of the witnesses for the canonisation process at Marienwerder offers several examples for popular doubts in saints and miracles. Finally, the Rhenish nobleman Arnold von Harff is included as a critical pilgrim who had his own thoughts about the veneration of relics.

\section{Occasional Events}

\section{Workshops}

Workshops are small conferences devoted to a specific topic or aspect of scepticism, bringing together different experts to present on the topic in question. In most cases, we design our workshops to include ample time for discussion in order to foster an exchange of ideas and help presenters improve their own research. The workshops are organised by MCAS fellows or team members. This allows them to present their distinctive field of study to other members of MCAS working in other disciplines or focussing on other topics. This encounter between different perspectives inspires very often new cooperations such as future interdisciplinary reading groups and workshops.

7-8 November, 2017

\section{Scepticism and Religion in Al-Ghazali, Maimonides, and Hume}

Convenors: Stephan Schmid, Universität Hamburg/Germany, Josef Stern, University of Chicago/USA, and Máté Veres, Université de Genève/Switzerland

In David Hume's Dialogues concerning Natural Religion, Cleanthes challenges Demea: 'Or how do you mystics, who maintain the absolute incomprehensibility of the Deity, differ from sceptics or atheists, who assert, that the first cause of All is unknown and unintelligible?' By the eighteenth century, we find questions of religion and scepticism tightly intertwined but this dialectic goes back to the ancient sceptics' critique of the gods and, when the three revealed monotheistic faiths encounter philosophy in the Middle Ages, it comes to embrace a rich variety of classical epistemological and metaphysical questions reconfigured in light of the medieval philosophical/ theological context. Not only do thinkers grapple with issues of how knowledge can be acquired-by direct intuition, human reasoning, and/or divine revelationbut also with the classical question of the very possibility of knowledge, at least in the realms of metaphysics and theology. And if knowledge cannot be possessed, 
how should one act: by denying the claims as Academic sceptics are said to have argued, by embracing them despite, or because of, their lack of rational justification as fideists recommend, or by simply suspending judgment to free oneself from the conflict between religion and philosophy as Pyrrhonists would have reacted? In this workshop, the participants proposed to explore parallels and discrepancies between three of the greatest philosophers in the three faiths to have canvassed this rich and inadequately studied territory between religion and scepticism leading to an even wider range of questions from atomism and causation to knowledge and the self: Abū Ḥāmid Muḥammad ibn Muḥammad Al-Ghazali (ca. 1058-1111), Moses Maimonides (ca. 1135-1204), and David Hume (1711-76). Although no claims of influence among these three thinkers are made, there are striking and sometimes uncanny moments of convergence and divergence in their arguments and strategies, whose mutual investigation can serve to illuminate the thought of each.

\section{Programme}

Stephan Schmid, Universität Hamburg/Germany

'Welcome and Introductory Remarks'

Máté Veres, Université de Genève/Switzerland

“"Philosophy's happy escape?” Ancient Scepticism and the Project of Hume's Natural History of Religion'

Andreas Lammer, Ludwig-Maximilians-Universität München/Germany

'Al-Ghazali’s Critical Theology'

Blake Dutton, Loyola University Chicago/USA

'Al-Ghazali and Hume on Causal Connection and Scepticism'

Josef Stern, University of Chicago/USA

'Maimonides' Guide and Hume's Dialogues: A Tale of Two Sceptics'

Mark Steiner, Hebrew University of Jerusalem/Israel

'David Hume: the First and Last "Kalamist"”

Ramona Winter, Humboldt-Universität zu Berlin/Germany

'Fictional Beliefs about the Self in Hume's Treatise. In what Sense are Fictional Beliefs Defective?'

Paul Russell, University of British Columbia/Canada and Göteborgs Universitet/ Sweden

'Hume's Scepticism and the Problem of Atheism' 
14-16 November, 2017

\section{Buddhism and Scepticism: Historical, Philosophical, and Comparative Perspectives}

Convenor: Oren Hanner, Universität Hamburg/Germany, in cooperation with the Numata Center for Buddhist Studies, Universität Hamburg/Germany

From their earliest stages, Buddhist traditions have displayed a sceptical attitude towards various types of accepted knowledge. Buddhist thinkers, beginning from the historical Buddha, questioned metaphysical assumptions, the realistic view of the world, and the reliability of our sources of knowledge, and expressed doubt about common social norms and religious views. In this way, philosophical scepticism played a pivotal role in the way Buddhist thought evolved. It served both as a method for arriving at a reliable and liberating understanding of reality and, as some argue, as an aspect of spiritual practice. The workshop on Buddhism and Scepticism investigated the place of scepticism in the development of classical Buddhist thought from historical and philosophical perspectives. From a historical standpoint, the conference explored the development of sceptical strategies in Buddhism and their relation to non-Buddhist systems of thought in Europe and Asia. From a philosophical point of view, it explored the ways in which sceptical arguments are used in Buddhist philosophical works, and how they resemble, and differ from, sceptical methods in other, non-Buddhist philosophies.

\section{Programme}

Oren Hanner, Universität Hamburg/Germany

'Welcome Addresses and Greetings'

Mark Siderits, Seoul National University/South Korea

'Keynote: Some Sceptical Doubts about "Buddhist Scepticism”,

Ethan Mills, University of Tennessee at Chattanooga/USA

'Nāgārjuna's Scepticism about Philosophy'

Georgios T. Halkias, University of Hong Kong/China

'The Soteriology of Scepticism: Historical and Philosophical Readings on Pyrrhonism and Buddhism'

Adrian Kuzminski, Independent Scholar

'The Evident and the Non-Evident: Buddhism through the Lens of Pyrrhonism'

Eli Franco, Universität Leipzig/Germany

'Why Madhyamaka Philosophy Is Not Sceptical' 
Amber Carpenter, Yale-NUS College/Singapore

'Ethics of Atomism and Scepticism'

Dong Xiuyuan, Shandong University/China

'The Epistemological Foundation of the Debate between the Samaniyya and the Early Mutakallimūn'

Serena Saccone, Österreichische Akademie der Wissenschaften/Austria

'Abandoning the Doubt through Doubting: cintāmayī prajñā in the *Vajracchedikāṭīkā by Kamalaśīla’

Vincent Eltschinger, École pratique des hautes études, Paris/France

'Between Faith and Scepticism: Probabilism as a Philosophical Approach to Scripture in Dharmakīrti's Thought'

Gordon F. Davis, Carleton University, Ottawa/Canada

'Buddhist Variations on Axiological Scepticism and Ethical Pluralism'

James Mark Shields, Bucknell University, Lewisburg/USA

'Sceptical Buddhism as Provenance and Project'

11-12 Dezember, 2017

\section{Visuelle Skepsis. Wie Bilder zweifeln}

(in German)

Convenor: Margit Kern, MCAS und Department of Art History, Universität Hamburg

Bilder als Erkenntnismedien spielen heute eine größere Rolle denn je. Die Bilderflut, unter anderem in den Neuen Medien, lässt sie allerdings auch problematisch werden. Vor diesem Hintergrund erhält die Frage größere Bedeutung, wie Bilder ihren eigenen Status als Erkenntnismedien problematisieren-zum einen ausstellen und zum anderen in Zweifel ziehen-können. Bisher wurde die Auseinandersetzung mit Positionen des Skeptizismus in der Kunstgeschichte geführt, indem man philosophische Strömungen einer bestimmten Zeit auf die Ikonographie von Gemälden bezog. Die wenigen Publikationen, die sich mit Skepsis beschäftigen, fragen vor allem danach, wie philosophische Texte ihren Niederschlag in Gemälden oder Druckgraphiken fanden. Die Tagung wählte hier einen anderen Zugang. Es wurden explizit die Diskurse untersucht, die nicht darauf zurückgehen, dass Texte des Skeptizismus in Bilder übersetzt wurden. Stattdessen wurde gefragt, wie Bilder aufgrund der ihnen eigenen medialen Struktur zum Ort von performativen Prozessen werden, die mit den dialogischen Strategien des Skeptizismus vergleichbar sind. Eine Hauptthese des Workshops lautete, dass hier Widersprüche und Negationen auftreten müssen, die den Charakter einer medialen Selbstbefragung haben. 


\section{Programm}

Margit Kern, Universität Hamburg

,Visuelle Skepsis-Eine Einführung‘

Jürgen Müller, Technische Universität Dresden

,Alle Kreter lügen. Überlegungen zu Pieter Bruegels "Misanthrop"،

Janne Lenhart, Universität Hamburg

,Zweifel am niederländischen Trompe-l’oeil: Cornelis Gijsbrechts' Rückseite eines Gemäldes“

Nicola Suthor, Yale University/USA

,Scheinhafter Realismus und die Spaltung des Bildes: Zu Caravaggios "Kreuzigung Petri" und "Paulussturz" in der Cappella Cerasi"

Karlheinz Lüdeking, Universität der Künste Berlin

,Caravaggios skeptischer Thomas (eine doppelte Gewebeprobe)

Meinrad von Engelberg, Technische Universität Darmstadt

,Die Kunst des "als ob”: Skepsis als ästhetische Prämisse im 18. Jahrhundert"

Werner Busch, Freie Universität Berlin

,Goyas “Caprichos”. Der Zweifel an der Wirksamkeit aufklärerischer Moral“

Gerd Blum, Kunstakademie Münster/Universität Wien

,Isosthenie und skeptischer Selbstwiderspruch: Manets "Déjeuner sur l'herbe”

Kristin Drechsler, Leuphana Universität Lüneburg

,Morandis Zweifel‘

Monika Wagner, Universität Hamburg

,Hinter Glas. Visuelle Dialoge mit einem transparenten Medium‘

Wolfgang Kemp, Universität Hamburg/Leuphana Universität Lüneburg

,Skepsis von Grund auf: Kurze Einblicke in werkgenetische Prozesse‘

Adi Louria-Hayon, Tel Aviv University/Israel

'The Dialectics of Failed Perception in Bruce Nauman's Art'

Beate Pittnauer, HBK Braunschweig

,Framing the real? Excluding the inventive? Über fotografische Gewissheiten und mediale Selbstzweifel ${ }^{\star}$ 
Margit im Schlaa, Berlin

,Blanks“

Sophia Kunze, Universität Hamburg

,Momente visueller Skepsis im Video Game‘

\section{Postersektion}

Anne-Kathrin Hinz, Friedrich-Schiller-Universität Jena

,"Spur Andreas B.” - Zweifel an der Darstellbarkeit von Geschichte?‘

Constanze Fritzsch, Staatliche Kunstsammlungen Dresden

,"Das Bild als Vorbild” A.R. Pencks Zweifel an der Sprache“

Lukas R.A. Wilde, Eberhard Karls Universität Tübingen

,"Methodischer Zweifel” an Comic- und Manga-Bildern? Bildobjekte, referential meaning und der dritte Zeichenraum‘

27-28 March, 2018

\section{A Touch of Doubt: On Haptic Scepticism}

Convenor: Rachel Aumiller, Universität Hamburg/Germany

Touch can serve as a 'reality check' that awakens an individual from her slumber. We pinch ourselves to confirm we are not dreaming. We slap a comrade across the cheek to bring him to his senses. In everyday speech, the sceptic is often presented as a 'Doubting Thomas' with the compulsion to touch what others accept on faith alone. Philosophical scepticism, however, casts doubt on the certainty of touch: Perhaps I am dreaming-dreaming even of the sensation of pinching myself awake. Is touch the guarantee of what is real? Or is the real precisely that which slips through the epistemologist's grasp?

\section{Programme}

Rachel Aumiller, Universität Hamburg/Germany

'Introduction: Framing the Sceptic as the Compulsive Toucher' 


\section{Noli me tangere}

Mirt Komel, Univerza v Ljubljani/Slovenia

'Touch Me (Not) and the Question of Sense Certainty'

Libera Pisano, Universität Hamburg/Germany

'The Profaning Touch that Challenges Authority'

\section{Religious Belief and the Imperative to Touch}

Bill Rebiger, Universität Hamburg/Germany

'A Magic Touch: The Imperative to Touch in Jewish Magic from the Hebrew Bible to the Middle Ages'

Robert Pfaller, Kunstuniversität Linz/Austria

'When to Touch-And What to Doubt'

\section{Haptic Cinema}

Rachel Aumiller, Ana Jovanović, Bara Kolenc, Mirt Komel, Goran Vranešević A Screening and discussion of a film project on touch and language

\section{Questioning the Paradox of Touch}

Ana Jovanović, Univerza v Ljubljani/Slovenia

'Touched in the Head: The s(k)epsis of Reason'

Goran Vranešević, Univerza v Ljubljani/Slovenia

'An Atom of Touch'

\section{Touching the Other | Touching Oneself}

Bara Kolenc, Univerza v Ljubljani/Slovenia

'The (Un)Touchable Touch of Pyramus and Thisbe: Doubt and Desire'

Jacob Levi, Johns Hopkins University/USA

“"Es wird Leib, es empfindet”: Hands and Auto-Affection in Husserl's Ideen II' 


\section{Blind-Touch}

José María Sánchez de León Serrano, Universität Hamburg/Germany

'Diderot's Letter on the Blind: Metaphysical Sobriety and the Priority of Touch'

Adi Louria-Hayon, Tel Aviv University/Israel

'The Weak Relations of Touch and Sight through the Passage of Lapsed Time'

Closing Discussion

'Emerging Concepts of Haptic Scepticism'

4 June, 2018

\section{Early Modern (Anti-)Scepticism}

Convenor: Stephan Schmid and Lukas Lang, MCAS, Universität Hamburg/Germany

The rise of scepticism in the early modern period led to new and innovative theories on both the sceptical and the anti-sceptical sides of the debate. This workshop aimed to investigate the sceptical and anti-sceptical elements in the philosophies of David Hume, Thomas Reid, and Baruch Spinoza. In particular, the questions, which were addressed, are first, in what respect these philosophers embraced scepticism or made use of sceptical strategies, and second, how, and by which means and at what cost, they resisted sceptical arguments.

\section{Programme}

Ramona Winter, Humboldt-Universität zu Berlin/Germany

'Are Fictional Persons a Problem for Hume?'

Lukas Lang, Universität Hamburg/Germany

'The Status of First Principles for Reid'

James Van Cleve, University of Southern California, Los Angeles/USA

'Two Ways to Skin a Sceptic: Reid's Realism and Kant's Idealism'

José María Sánchez de León Serrano, Universität Hamburg/Germany

'Spinoza on Adequacy and Common Notions' 


\section{Lecture Series 'Feminism and Scepticism'}

The Maimonides Centre established a lecture series which focusses on feminist approaches to and perspectives on scepticism. The Centre invites researchers to give a public lecture on this topic, and-following this lecture-to meet with the female researchers in order to share their experiences and career paths in their academic systems. The female fellows expressed the wish to learn more about academic career advancement opportunities in different countries.

\section{December, 2017}

Judith R. Baskin, University of Oregon, Eugene/USA

\section{Rabbinic Forensics: Distinguishing Egg White from Semen in bGittin 57a}

This lecture began with a discussion of a brief passage within a passage in Babylonian Talmud, Gittin 57a that demonstrates how rabbinic knowledge of a forensic technique for distinguishing egg white from semen protected a woman from her husband's fabricated accusation of adultery. Judith Baskin then went on to discuss how this investigative procedure is cited in medieval and early modern Jewish exegeses of the story of Joseph and Potiphar's wife (Genesis 39), where the same forensic test is used to absolve a man who was falsely accused of rape by a woman. Interestingly, this scientific test is also cited in a medieval Muslim source. Additionally, the lecture looked at the values these narratives attach to female passivity and agency, and establishes, as well, how the anecdote about the husband who was found guilty of falsely accusing his wife in the talmudic passage is also part of a late ancient polemic against Christianity.

30 January, 2018

Tsippi Kauffman, Bar-Ilan University, Ramat Gan/Israel

Hasidism and Gender: Shades of Scepticism

Did the hasidic movement's revolution of the Jewish world include women? The lecture examined the case of Temer'l Sonenberg-Bergson, a patron of Polish șaddiqim. Using feminist criticism of religion studies, Tsippi Kauffman demonstrated the implications of the patriarchal approach to setting the boundaries of religious phenomena -in this instance, the question of whether this extraordinary woman may properly be called a hasida. A review of several hasidic stories showed how Temer'l expressed her Hasidism and how she was viewed within hasidic circles as a sort of hermaphrodite, with scepticism towards both her femininity and her religiosity. 


\section{Maimonides Lectures on Scepticism}

The Maimonides lectures were established to invite international researchers to give a talk within the field of scepticism. The lectures are recorded and published on the webpage of the Centre in order to make them available to a larger audience.

21 February, 2018

Moshe Halbertal, Hebrew University of Jerusalem/Israel

Facing Uncertainty: Maimonides' Concept of Law

Uncertainty is an essential feature of the human condition; it is simultaneously a source of deep anxiety and of thrill. The present state of the world, its past, and what it holds for us in the future are frequently unknown to us. This lecture examined the moral and legal implications of uncertainty, exploring the subject through Maimonides' legal work as it faces the challenges of uncertainty in Jewish law. Jewish law takes a keen interest in this feature of the human condition, and it has vast and intense discussions which address the following question: 'what are the norms that have to be applied in conditions in which we do not know the facts of the matter?' The talmudic tradition also addresses situations in which we might have a full grasp of the facts of the matter, but deep uncertainty about the proper norms that have to be applied to these facts. In such cases, our uncertainty is not factual but normative, and while affirming our normative uncertainty, the Talmud attempts to formulate rules that will be applied in conditions of uncertainty about the rules. What we can learn from these attempts to regulate conditions of uncertainty is how Maimonides understood its moral and legal significance and how his attempts to regulate these conditions reflected his conception of Jewish law.

\section{May, 2018}

Christoph Schulte, Universität Potsdam/Germany

Metaphysical Scepticism concerning the Philosophy of History: Mendelssohn's Arguments against the Progress of Humankind

In his seminal work Jerusalem (1783), Moses Mendelssohn explicitly refuses his close friend Lessing's ideas of a successive education of humankind and a general progress in the development of human rationality and morality in world history. This scepticism towards the upcoming modern philosophy of history and the idea of an infinite progressive evolution of humankind from the beginnings of world history is based on the principles of Mendelssohn's metaphysics, his anthropology, and his philosophy of natural law. This lecture discussed Mendelssohn's arguments and their philosophical relevance in some philosophers of the twentieth century. 
29 May, 2018

Glenn Dynner, Sarah Lawrence College, Yonkers/USA

'I began to have doubts:' Defection from Orthodoxy and the Traditionalist Jewish Response in Twentieth-Century Poland

The early twentieth century was a period of accelerated acculturation among Polish Jews. As many young people discovered rationalist literature and joined modern political movements, rabbinic and hasidic leaders evinced panic over youth defections and the 'emptying-out' of their study halls. However, secularising Jewish youth in the Second Polish Republic encountered formidable barriers to integration, including restrictions on university admissions and frequent physical assaults on campuses. Many found themselves in a state of cultural limbo. At the same time, hasidic and rabbinic leaders revitalised their institutions by appropriating secularist educational, political, and institutional modes-a defensive acculturation strategy that inadvertently transformed Polish Jewish traditionalism itself. This lecture examined both Polish Jewish youth 'defections' and the innovative traditionalist responses to this perceived crisis.

$12-15$ March, 2018

\section{International Conference: Abulafia and the Early Maimonideans: Trends, Approaches, and Sceptical Strategies}

Convenor: Racheli Haliva, Universität Hamburg/Germany

The conference focussed on the different trends and sceptical attitudes Maimonideanism took in the thirteenth and fourteenth centuries by examining various approaches to major religious topics such as the nature of the Torah, the commandments, the Hebrew language, the people of Israel, and the land of Israel. This comparative approach points to distinctive philosophical trends-as represented by ibn Tibbon, Shem Tov ibn Falquera, Joseph ibn Caspi, Levi ben Abraham, Isaac Albalag, Moshe Narboni, Zerahyah Hen, and Hillel of Verona-focussing on major Jewish religious topics. Among these trends, the place of Abraham Abulafia and the early writings of R. Joseph Gikatilla, who wrote some forms of commentaries on Maimonides' Guide of the Perplexed stands out. The questions to be asked were whether it is possible to draw a map of radical versus conservative Maimonideanism and whether the two kabbalists are as radical as the philosophers when dealing with the same topics. 


\section{Programme}

\section{Life in Naples}

David Abulafia, University of Cambridge/UK

'Naples as Mediterranean Crossroads'

Moshe Idel, Hebrew University of Jerusalem/Israel

'Abulafia's Commentaries on the Guide of the Perplexed'

Gitit Holzman, Levinsky College Tel Aviv/Israel

'Commentaries on the Guide of the Perplexed II'

Yossi Schwartz, Tel Aviv University/Israel

'Abulafia and Hillel of Verona on the Guide of the Perplexed'

Arje Krawczyk, Jewish Historical Institute, Warsaw/Poland

'Inner Speech (endophasia) in the Thought of Maimonides and Abulafia'

\section{Torah, Tablets of Stone, and Mount Sinai's Revelation}

Steven Harvey, Bar-Ilan University, Ramat Gan/Israel

'The Law of Moses in Maimonides, Abulafia, and Maimonideans'

Daniel Davies and Racheli Haliva, Universität Hamburg/Germany

'Tablets of Stone-between Maimonides and Abulafia'

Adam Afterman, Tel Aviv University/Israel

'Kabbalistic Reading of Maimonides' Concept of Revelation'

Fabrizio Lelli, Università del Salento/Italy

'Translations and Commentaries of Abulafia'

\section{Between Prophecy and Philosophy}

Haim Kreisel, Ben-Gurion University of the Negev, Beer-Sheva/Israel 'Maimonides and Abulafia on Prophecy'

Elke Morlok, Goethe-Universität Frankfurt/Germany

'The Status of the Text and the Use of Language in Maimonides and Abulafia' 
Ofer Elior, Ben-Gurion University of the Negev, Beer-Sheva and Hebrew University of Jerusalem/Israel

'The Account of the Chariot in Maimonides, Abulafia, and Provençal Thinkers'

The Land of Israel and the Hebrew Language

Josef Stern, University of Chicago/USA

'The Role of Language in Maimonides and Abulafia's Thought'

Hanna Kasher, Bar-Ilan University, Ramat Gan/Israel

'Maimonides, Abulafia, and Joseph ibn Kaspi on the Hebrew Language'

Zev Harvey, Hebrew University of Jerusalem/Israel

'Maimonides, Abulafia, and Spinoza'

José María Sánchez de León Serrano, Universität Hamburg/Germany

'Response'

\section{Lecture Series 'Reason and Revelation in Jewish Tradition'}

Organised by the Institute for Jewish Philosophy and Religion, in cooperation with MCAS

Convenor: Lilian Türk, Institute for Jewish Philosophy and Religion, Universität Hamburg/Germany

The lectures introduced Jewish thought to the interested public and exposed the relationship between reason and revelation in specific Jewish writings. They revolved around the following questions: under which circumstances can we speak of reason within the framework of Judaism? Can we erroneously read reason into the sources of heavenly revelation? How can the presupposition of reason/ratio be justified by Jewish thinkers and deduced from traditional Jewish sources? Does reason concur with faith, or are they exclusive epistemological spheres?

\section{Programme}

16 March, 2018

Giuseppe Veltri, Universität Hamburg/Germany

Glaube und Vernunft im Judentum: Eine philosophisch-skeptische Einführung 
25 March, 2018

Meir Buzaglo, Hebrew University of Jerusalem/Israel

The One: Towards a Talmudic Approach

5 May, 2018

Bill Rebiger, Universität Hamburg/Germany

Gershom Scholems Erforschung der Kabbala und die Frage nach Vernunft und

Offenbarung im Judentum

7 May, 2018 [Maimonides Lecture]

Christoph Schulte, Universität Potsdam/Germany

Metaphysical Scepticism concerning the Philosophy of History: Mendelssohn's

Arguments against the Progress of Humankind

14 May, 2018

Ze'ev Strauss, Universität Hamburg/Germany

Wenn die Offenbarung selbst die hypostasierte Vernunft Gottes ist: Der

Offenbarungsbegriff des Philon von Alexandria

28 May, 2018

Elchanan Reiner, Tel Aviv University/Israel

The 'Ten Questions' of Eliezer of Eilenburg-Scepticism, Heresy or Exegesis? An Alternative Reading

4 June, 2018

Daniel Davies, Universität Hamburg/Germany

The Jacobs Affair: Revelation and Schismatic Jewish Theology

6 June, 2018

Lilian Türk, Universität Hamburg/Germany

Offenbarungsverständnis und Vernunftkritik im jüdischen religiösen Sozialismus

11 June, 2018

Aryeh Botwinick, Temple University, Philadelphia/USA

Negative Theology in the Context of Rabbi Akiva as a Rabbinic Precursor and Infinity as the Point of (Non-)Contact 
13 June, 2018

Yair Lorberbaum, Bar-Ilan University, Ramat Gan/Israel

The Rise of Halakhic Religiosity, of Mystery, and Transcendence in the Jewish Tradition

18 June, 2018

Michael Engel, Universität Hamburg/Germany

Apologetic Tendencies vs. Apologetic Works: Evaluating the Historiography of Medieval Jewish Thought

25 June, 2018

Rachel Aumiller, Universität Hamburg/Germany

The Comic Slapstick of Resistance and Revelation: Walter Benjamin and WWII Political Satire

27 June, 2018

Libera Pisano, Universität Hamburg/Germany

The 'Speaking Language' of Revelation beyond Reason: Franz Rosenzweig's Grammatical Thought

2 July, 2018

Daniel Boyarin, University of California, Berkeley/USA

Kommentar innerhalb der Grenzen der bloßen Vernunft: The Philosophical Grounds of Pilpul

9 July, 2018

Michela Torbidoni, Universität Hamburg/Germany

Challenging Religious Authorities: The Scientific Commitment of the Jews in Seventeenth Century Venice 
29 July-3 August, 2018

\section{Second Summer School}

Sceptical Strategies, Methods, and Approaches in the Middle Ages: Jewish, Christian, and Islamic Traditions

The second Summer School was focussing on major sceptic concepts, strategies and key terms in medieval Hebrew, Arabic, and Latin literature. Participants and instructors focussed on sceptical and anti-sceptical enquiry of concepts of truth and knowledge as well as sceptical methods of doubting and arguing. The Summer School offered a unique platform to discuss the tension between philosophy and faith, and between reason and revelation within medieval discourses. Participants were engaged with primary Hebrew, Latin, and Arabic texts. The aim was to provide participants with the tools to examine scepticism and anti-scepticism within Jewish, Christian, and Islamic contexts in relation to attaining true knowledge.

Course leaders were Racheli Haliva and Giuseppe Veltri. They were supported by an international team of experts in scepticism from the fields of medieval philosophy and religious studies: Elena Baltuta, Guido Bartolucci, Daniel Davies, Heidrun Eichner, Yehuda Halper, Elon Harvey, Steven Harvey, Gitit Holtzman, Henrik Lagerlund, Giovanni Licata, Ariel Malachi, Yoav Meyrav, and Ronny Vollandt.

The Summer School was attended by 15 participants from Argentina, Austria, China, Germany, Israel, Morocco, the United Kingdom, and the United States.

\section{MCAS Participation in External Conferences (Selection)}

6-10 August, 2017

\section{$17^{\text {th }}$ World Congress of Jewish Studies in Jerusalem/Israel}

Panel: Scepticism and Anti-Scepticism in Medieval Jewish Philosophy and Thought

\section{Giuseppe Veltri}

\section{Saadiah's Anti-Scepticism among Sceptical Movements in the Middle Ages}

In his introduction and first section of the Emunot ve-De'ot, Saadiah makes a genuine attempt and devotes great efforts to rebutting and refuting sceptical movements that were active in his time. He argues that mistakes and changes of opinion are part of the quest for the truth. These mistakes and changes of opinion are not to be taken, according to Saadiah, as a proof that nothing can be known. The fact that Saadiah 
devotes in his work long discussions to deal with sceptical problems should not be underestimated. Indeed, it is not a purely introductory question but rather a historical testimony of an extent phenomenon of sceptical theories in his time. The lecture focussed mainly on the presence of sceptical movements before and during Saadiah's time as reflected in his work(s). Moreover, the analysis of Saadiah's anti-scepticism was addressed through the lenses of modern studies on medieval scepticism.

Ariel Malachi

'Our eyes saw, not a stranger's:' Sceptical Aspects in Epistemological Conceptions of Halevi, Ibn Daud and Maimonides, through the Question of the Certainty of Tradition

What is scepticism, and what is the definition according to which one can be characterised as sceptic, is a fascinating question. However, be our answer to this fundamental enquiry wide or narrow, inclusive or exclusive, casting doubt is clearly at its basis. According to the logical Islamic-Aristotelian tradition, the distinction between an argument whose conclusion is certain and an argument whose conclusion is uncertain, depends on the distinction between the value of a demonstrative argument and the value of a dialectical or rhetorical arguments. In this context, it is noteworthy to analyse in which manner Islamic and Jewish thinkers faced the question of the certainty of tradition. In the talk, the following arguments were addressed:

1. With regard to this question, one can distinguish Al-Farabi's position from that of Ibn Sina's; while Al-Farabi doubts tradition, and states that the epistemological status of prepositions which derives from tradition is uncertain, Ibn Sina, on the other hand, argues that in case of consecutive tradition, the consecutiveness might unravel the doubt we attribute to these prepositions, and one may accept them as certain.

2. The analysis of relevant texts reveals that this distinction found its way to the Jewish thought in the following surprising way: Halevi, much like Maimonides, supports Al-Farabi's more doubtful attitude, while Ibn Daud emphasises the less sceptical approach of Ibn Sina.

Racheli Haliva

\section{The Esoteric Scepticism of the Rational Jewish Thinker: Isaac Polqar on the Talmud and the Commandments}

The tension between revelation and reason, between tradition and intellectual investigation, has occupied thinkers of all religions. These thinkers, who sought to reconcile faith and philosophical enquiry, were obligated to their religious traditions on the one hand, and to philosophical principles on the other. Naturally, the traditionalists were sceptical towards the rationalists, for, according to their view, the philos- 
ophers shake the foundations of faith. At the same time, the philosophers were sceptical towards the traditionalists, arguing that some aspects of tradition contradict philosophical principles and therefore must be re-interpreted.

Isaac Polqar, the Jewish philosopher from the fourteenth century, was intrigued by the relationship between philosophy and Judaism. Despite his attempt to exoterically argue that there is no contradiction between philosophical principles and the principles of Judaism, he esoterically challenges the authority of basic religious foundations such as the Mosaic Law.

In this lecture, it was shown how Polqar's sceptical approach towards some traditional views strengthens his philosophical/natural point of view, as a result of which philosophy is placed in a superior position than tradition, or more precisely, aspects of tradition.

\section{Bill Rebiger}

\section{Sceptical Strategies Used by Simone Luzzatto and Leon Modena in their Examination of Kabbalah}

The Venetian rabbis Simone Luzzatto (1583-1663) and Leon Modena (1571-1648) adopted a critical approach towards Kabbalah; and yet their criticism was manifested in different ways. While Leon Modena devoted an entire book written in Hebrew, his Ari Nohem ('Roaring Lion'), to a comprehensive and sharp attack on Kabbalah, Simone Luzzatto included merely a few pages in his Discorso circa il stato degli Hebrei et in particular dimoranti nell'inclita città di Venetia ('Discourse Concerning the Condition of the Jews, and in particular those living in the Fair City of Venice') where he presented in Italian apparently only several basic concepts and historical data of Kabbalah. In the lecture, various sceptical strategies inherent in their examination of Kabbalah were compared and discussed. Thus, the lecturer presented the complex relationship between the purpose of the writing, the choice of language, the addressed audience, the modes of publication, and sceptical strategies.

5-8 March, 2018

\section{Annual Conference 2018, European Academy of Religion (EURARE) in Bologna/Italy}

Panel: Jewish Philosophy: A Controversial Issue between Judaism and Christianity (Seventeenth and Eighteenth Centuries)

Guido Bartolucci, Libera Pisano, and Michela Torbidoni

The meaning of Jewish philosophy has been, is, and continues to be a controversial issue within the broad field of Jewish studies. It would be paradoxical to attempt to 
draw the boundaries of this category, since it is at the same time a conjunction and a disjunction of two different perspectives. In fact, the concept of Jewish philosophy on the one hand addresses the secular tendencies of Jewish thinking and its critical approach to religion, and on the other hand necessarily involves the results of the dialogue between Jewish and Christian traditions. In this regard, the panel aims to explore the blurred boundaries of such a significant subject by presenting the point of view of some Christian and Jewish authors, such as Johann Franz Budde, Simone Luzzatto, and Moses Mendelssohn, and how they have developed a philosophical interpretation of Judaism from this.

15-19 July, 2018

\section{$11^{\text {th }}$ EAJS Congress in Krakow/Poland}

\section{Panel: Jewish Scepticism}

Giuseppe Veltri

Jewish Scepticism? Origins and Development of a Definition

It is perhaps no surprise that the period in which the main concept of a 'Jewish philosophy' was developed, i.e. early modernity, is also the origin of the idea of a 'Jewish' scepticism. In the lecture, Veltri dealt with the many elements which created a Jewish sceptical tradition in the early modern period parallel to the discussion of a philosophia perennis that was developed in Christianity in an attempt to dogmatise the Jewish philosophical tradition by assuming a genealogy of wisdom as well as mystical or kabbalistic speculation to back it. The curious element which will be analysed is that discussion of the sceptical 'nature' (or, to use a sceptical category, 'attitude') of Judaism originated contemporaneously in two different areas, in northern Italy, particularly in Venice, and in Germany.

\section{Guido Bartolucci}

\section{Simone Luzzatto's Political Thought: Between Scepticism and Reason of State}

Simone Luzzatto's political thought has been interpreted by several scholars as being linked to the tradition of the Reason of State, to which the Venetian rabbi makes constant reference in his work, particularly in the Discorso. Upon analysing Luzzatto's works in depth, however, it is possible to recognise other fragments of a political reflection that cannot be traced back to the tradition of Reason of State and which in some cases is contrary to it. By comparing the different political positions expressed by Luzzatto in his works, a new political thought emerges, transformed by using the sceptical tradition. In fact, in both the Discorso and the Socrates, Luzzatto recognises 
the impossibility of formulating a 'universal' political theory, and identifies the sceptical concept of the 'probable' as the only guide that man has for living in a social community.

The paper aimed to compare Luzzatto's different positions and to recognise the sources of his most radical interpretation, the politics of the probable, which may be useful in order to understand the influence of scepticism in Jewish and Christian political thought in seventeenth-century Europe more generally.

\section{Michela Torbidoni \\ Challenging the Authority of Antiquity: The Influence of Francis Bacon on Simone Luzzatto's Sceptical Thought}

The aim of the paper is to explore the purposes underlying the sceptical enquiry led by Rabbi Simone Luzzatto in his works. Through his sceptical arguments, Luzzatto develops a criticism of human knowledge specially aimed to deconstruct the authority of ancient dogmatic wisdom. In this respect, Torbidoni argued that Luzzatto's project was deeply influenced by the reading of Francis Bacon's philosophy, wellknown for having promoted a reformation of human learning by challenging the relationship between antiquity and modernity and thus the method whereby knowledge is apprehended and passed on. The statement, which is based on relevant indirect quotations of Bacon's works raised throughout Luzzatto's writings, intends to disclose the crucial role played by this source in understanding the arguments and goals of Luzzatto's scepticism. Bacon's philosophy fulfils a double task in this regard: on the one hand, it provides a significant speculative pattern to be taken into account by reading some of the main issues raised by Luzzatto, like those of time, dogma, free critical investigation, sincere truth, and temporary suspension of judgement. On the other hand, this source narrows the field of research upon the still-unknown intellectual interlocutors of Luzzatto. As no other Jewish reader of Bacon's writings is known so far, this source builds a bridge between Luzzatto and those Venetian Christian intellectuals who were closer to the Protestant world and highly critical of both the Roman Church and the Scholastic tradition, such as Paolo Sarpi and his circle.

\section{Libera Pisano}

\section{Sprachkrise as Sceptical Philosophy of Language}

The so-called Sprachkrise is a complex phenomenon of language critique diffused in the philosophical and literary debate among poets and intellectuals before World War I. The specific trait of the theoretical constellation that was characterised by the collapse of language as an epistemological, logical, and ontological tool was to consider linguistic boundaries. In this contribution, Pisano investigated this phe- 
nomenon for two reasons: firstly, the Sprachkrise helps us to better understand how the critique of language became the focus of philosophical thought at the beginning of the last century long before the linguistic turn; secondly, this phenomenon particularly acquired special attention among German-Jewish thinkers. In fact, since all these authors have a double cultural background in common, or better, a double belonging both to Jewish tradition and to German philosophy, their sceptical attitudes or critical distance towards language also have their premises in autobiographical factors. Thanks to the mediation of Fritz Mauthner, whose work was the trait d'union between literature and critical thought, the phenomenon of Sprachskepsis spread throughout the milieu of German-Jewish philosophy; in fact, it involves the whole generation of thinkers whose elective affinities were analysed by Löwy in Redemption and Utopia, i.e. Landauer, Benjamin, Buber, Scholem, Bloch, and others, who linked together language, messianism, libertarian utopias, and romanticism.

\section{Bill Rebiger}

\section{Sceptical Elements in a Dogmatic Stance: Isaac Polqar against the Kabbalah}

Despite the generally accepted opinion that the Jewish Averroists were-at least ultimately-dogmatics or anti-sceptics, certain sceptical elements and strategies can notwithstanding be detected in their works. Rebiger presented a case study devoted to the Jewish Averroistic philosopher and polemicist Isaac Polqar (second half of the thirteenth century-ca. 1330) and his attack on kabbalists included in his main work 'Ezer ha-Dat ('In Support of the Religion'). According to Polqar, the kabbalists are dangerous because they claim to have knowledge that does not accept the philosophical methods and logical rules of Aristotle. In contrast, the kabbalists' supposed knowledge is supplied by an esoteric tradition reaching back to the time of the prophets, as they claim. Therefore, following the epistemological criteria defined by Maimonides, Kabbalah cannot be accepted as a certain source of knowledge. Accordingly, Polqar tried to undermine the authority and legitimation of the kabbalists' claims about a traditional knowledge by using various sceptical elements in his argumentation.

Israel Netanel Rubin

\section{Omnipotence, Scepticism, and Logic: What Is Remaining When Everything Is Possible?}

God is almighty, as every child knows, at least since the time when monotheism conquered the cultural world. However, can God really do everything? Is He able to create a square with a diagonal which has the same length as its side? Can God create another God like Himself? Can God commit suicide? Among the family of such quaint heretical paradoxes, the most famous is that about God's ability to create a 
stone that He is unable to lift. So, the principal question is whether God's omnipotence, which originally meant His superiority over physical laws, also extends to the world of logic and mathematics. But it becomes clear that this question leads in fact to the basic question about the rationality of religion and even the issue of whether a rational religion is possible at all. One of the solutions to the problem, adopted both by philosophers like Descartes and by Jewish kabbalists and mystics in recent generations, indeed prefers the totality of divine omnipotence over any other consideration. This position leads to what the American philosopher Alvin Plantinga called 'universal possibilitism,' since even the most basic laws of logic are declared to be contingent and determined by the arbitrary will of God alone. The result of this is that everything is possible, that anything can be, and that there is no situation, sentence, or object whose existence, or non-existence, can be absolutely determined. Here, then, is the touching point between the problem of divine omnipotence and the sceptical worldview. Each of them begins at a different point of origin, but eventually they find themselves draining together into the impasse of philosophical nihilism that comes from unlimited possibilitism.

\section{José María Sánchez de León Serrano}

\section{Spinoza on the Cartesian Circle}

The so-called 'Cartesian circle' designates a predicament in Descartes' attempt to prove God's existence and eliminate sceptical doubt. The predicament can be described as follows. Descartes argues that we cannot be certain of anything-even of the most evident truths, such as mathematical truths-as long as we do not know if God exists. However, God's existence is not self-evident and requires a demonstration. Yet such a demonstration appears to be impossible, for a demonstration must be based on certain premises and we have just assumed that nothing is certain. In this paper, Sánchez de León focussed on Spinoza's approach to this predicament. Although Spinoza was strongly influenced by Descartes, it is usually assumed that the just described problem plays no role in his philosophy, due to Spinoza's full-fledged rationalism. The lecturer argued, on the contrary, that the Cartesian circle resurfaces in Spinoza's philosophy precisely because of its rationalistic character. Moreover, Sánchez de León showed how Spinoza circumvents the difficulty through a proof of God's existence that is simultaneously cosmological and ontological.

\section{Ze'ev Strauss}

On the Boundary between Dogmatic Platonism and Academic Scepticism: Philo of Alexandria's Sceptical Judaism

It is by no means a new revelation within the scholarly work done on Philo of Alexandria thus far that his multi-layered body of thought has recourse to various ele- 
ments of the rich philosophical tradition of academic scepticism. The leading Philo scholar David T. Runia draws our attention to this fact when he alludes to the 'mixture of scepticism and dogmatism' present in Philo's Jewish philosophy $(1986,129)$. This view might come as a surprise to some, since Philo can be perceived as a dogmatist in the truest sense of the word: on the one hand a dogmatic Platonist, and on the other hand and a fortiori a dogmatic Jewish thinker who strictly adheres to the tenets of Mosaic faith. In his paper, Strauss endeavoured to show that Philo cannot be easily cast aside as merely a dogmatic exegete of scripture who occasionally makes only eclectic references to Greek philosophy. Rather, he should be considered a serious metaphysician, who quarrels with sceptical notions in order to delineate his own speculative understanding of Jewish philosophy. Strauss argued that Philo held the stance that without the revealed truth of Judaism, we are forced to resort to a radical sceptical position, where we are left to battle for our mere opinions without ever being able to attain basic metaphysical knowledge of reality. He also aimed to concretely demonstrate a point touched on by Carlos Lévy (2010, 94), namely how Philo sophisticatedly utilises sceptical patterns of thought for the formulation of his apophatic theology. 